\title{
The orthodox liturgical year and its theological structure
}

\begin{tabular}{|c|c|}
\hline $\begin{array}{l}\text { Author: } \\
\text { Dan A. Streza }\end{array}$ & \\
\hline $\begin{array}{l}\text { Affiliations: } \\
{ }^{1} \text { Department } \\
\text { Theology, Fact } \\
\text { Theology, Luci } \\
\text { University of S } \\
\text { Romania }\end{array}$ & $\begin{array}{l}\text { f Orthodox } \\
\text { Ity of Orthodox } \\
\text { an Blaga } \\
\text { ibiu, Sibiu, }\end{array}$ \\
\hline $\begin{array}{l}{ }^{2} \text { Department } \\
\text { and Historical } \\
\text { Faculty of The } \\
\text { Religion, Univ } \\
\text { Pretoria, Pret } \\
\text { South Africa }\end{array}$ & $\begin{array}{l}\text { f Systematic } \\
\text { Theology, } \\
\text { ology and } \\
\text { ersity of } \\
\text { ria, }\end{array}$ \\
\hline $\begin{array}{l}\text { Research Proj } \\
\text { Project Leade } \\
\text { Project Numb }\end{array}$ & $\begin{array}{l}\text { ect Registration: } \\
\text { r: J. Pillay (D) } \\
\text { er: } 04653484\end{array}$ \\
\hline $\begin{array}{l}\text { Description: } \\
\text { The author is } \\
\text { the research a } \\
\text { Prof. Dr Jerry } \\
\text { of Theology ar } \\
\text { University of P }\end{array}$ & $\begin{array}{l}\text { articipating as } \\
\text { ssociate of Dean } \\
\text { illay, Faculty } \\
\text { d Religion, } \\
\text { retoria. }\end{array}$ \\
\hline $\begin{array}{l}\text { Correspondin } \\
\text { Dan Streza, } \\
\text { dan.streza@u }\end{array}$ & $\begin{array}{l}\text { g author: } \\
\text { bsibiu.ro }\end{array}$ \\
\hline $\begin{array}{l}\text { Dates: } \\
\text { Received: } 14 \\
\text { Accepted: } 09 \\
\text { Published: } 02\end{array}$ & $\begin{array}{l}\text { pr. } 2021 \\
\text { uly } 2021 \\
\text { Sept. } 2021\end{array}$ \\
\hline $\begin{array}{l}\text { How to cite th } \\
\text { Streza, D.A., } 2 \\
\text { orthodox litur } \\
\text { its theological } \\
\text { HTS Teologies } \\
\text { Theological St } \\
\text { a6742. https: } \\
\text { 10.4102/hts.v }\end{array}$ & $\begin{array}{l}\text { is article: } \\
021, \text { 'The } \\
\text { gical year and } \\
\text { structure', } \\
\text { Studies/ } \\
\text { udies } 77(4) \text {, } \\
\text { /doi.org/ } \\
77 \text { i4.6742 }\end{array}$ \\
\hline $\begin{array}{l}\text { Copyright: } \\
\text { (C) 2021. The } \\
\text { Licensee: AOS } \\
\text { is licensed un } \\
\text { Creative Com } \\
\text { Attribution Lic }\end{array}$ & $\begin{array}{l}\text { uthors. } \\
\text { IS. This work } \\
\text { ler the } \\
\text { nons } \\
\text { ense. }\end{array}$ \\
\hline Read online: & \\
\hline 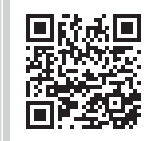 & $\begin{array}{l}\text { Scan this QR } \\
\text { code with your } \\
\text { smart phone or } \\
\text { mobile device } \\
\text { to read online. }\end{array}$ \\
\hline
\end{tabular}

The concept of 'liturgical year' indicates a reference to the meaning of the measuring units of civil time, and especially to the cosmic entities that determine the general rhythm of time - the sun and the moon. Interestingly, the liturgical time depends both on the structure of civil time, and, on the two discrete systems of the solar and lunar cycles, which have always been underpinnings of time measuring. The special importance and influence that the cosmical rhythms exert on the entire human life are also felt in the structure and theology of the liturgical time, where it signals the attempt to merge and reconcile the cosmical solar and lunar cycles within the liturgical year. This leads to a unique theology, expressing the powerful synthesis of the variability of the lunar cycle compared to the structure of the solar year's fixed dates.

Contribution: This research reveals the unique orthodox perspective on both civil and liturgical time, expressing their profound theological meaning, as a conscious, permanent reflection upon the mysterious, yet real, presence of Christ in the divine services of the Church.

Keywords: liturgical time; orthodoxy; liturgics; anthropology; feast; calendar; Chronos; Kairos.

\section{Introduction}

In trying to explain the notion of 'liturgical year', many definitions have been formulated. Amongst those, the simplest one that is also strictly structural claims that: 'the liturgical year is based on a series of holidays and commemorations that are celebrated throughout a civil year, year after year ...' (Vismans \& Hollaardt 1965:1303). This definition highlights the special importance of the tropical year, as well as its normative character that allows the holidays to be variable and complex.

From a theological and structural point of view, the liturgical year is a conscious theological reflection of the church upon the Mystery of Christ, who truly manifests himself in the rituals of the church, who gives himself to those who come to him and thus sanctify the whole world through them (Schmemann 2002:138-139).

This double perspective on the liturgical life of the church as a divine-human 'synergy' is deeply rooted in the tradition of the Holy Fathers. It emphasises the unity and the living, dynamic faith of the communities that make up the church, and that points to a conscious and personal reference to the mystery of Christ's divine and human person that is actualised through the divine services that are centred on the Paschal Mystery of the Saviour's Sacrifice and Resurrection.

\section{The defining elements of the liturgical year}

The church does not refresh the memory of the faithful through commemorations conducted through feasts, fasts, various memorials and religious services that occur sequentially and recur in a particular order each year. Rather, Christ is the one who makes himself present in the holy mysteries so that every believer is called to assume a journey on a spiritual ascent along with him, by reliving the highlights of the saviour's life and activity in a mystical and sacramental way. This spiritual roadmap, whose goal is man's attainment of perfection in Christ, sits under the sign of temporality and perishability of the material world, which make up the context where human freedom manifests. By the 'synergetic' collaboration between man and God, through divine grace, man is thus enabled to secure his place in the kingdom of God in a mystical, concealed and incomplete way in this life, and plenary, in the eternal one (Streza 2017:139-140).

Note: Special Collection: Lucian Blaga University, Sibiu, Romania, sub-edited by Daniel Buda (Lucian Blaga University) and Jerry Pillay (University of Pretoria). 
These liturgical 'rhythms' have very deep roots in the Jewish ceremonial tradition because the church has arisen from within the Jewish people. It took over from Judaism the liturgical matrix, which the Ecclesia then filled with new meaning through the Eucharist, thus fulfilling the purpose of the chosen people's worship, as a foreshadowing of the true worship.

However, the church has evolved as a living entity, blending different local traditions, and is always struggling to preserve 'unity in diversity'. Similar to many other ecclesiastical structures, the concept of 'liturgical time' has interacted gradually with other traditions since the early centuries, and according to Thomas Talley, the gospel tradition and its liturgical development formed the complex period of the liturgical year (Talley 1991:231-239).

In the beginning, Christians took over the 'weekly liturgical rhythm', which revolved around a reference day, the 'Sabbath', as well as the 'annual liturgical rhythm', which had at its heart the feast of 'Passover' (Nisan 14), along with two other large celebrations devoted to pilgrimages: the 'Pentecost - the Feast of Weeks' (50 days after Easter) and the 'Feast of Tabernacles - Sukkot' (Tishri 15) (Oancea 2007:214-216).

The fact that the saviour was suffering while the Jews were celebrating the Passover was by no means a chance occurrence, for he was the fulfilment of the true meaning of the Jewish Passover, and he gave the world the gift of his resurrection, the New Pascha.

Whereas for the Jews the Pascha is celebrated only once a year, on Nisan 14, for Christians, Easter is celebrated on the first day of each week, that is, on each Sunday, which is the eighth day, the beginning of the new 'aeon'. Also, the annual celebration of the sacrifice and resurrection of the Lord acquires a profound mystical-symbolic significance, as the historical event is doubled by a deep eschatological and soteriological meaning. Therefore, from the very beginning, the Christian calendar, just like the Jewish one, had two centres of reference: the Sunday - the Lord's Day, and the central annual celebration - the Pascha. All the other feasts and liturgical days revolve around these two.

Thus, by establishing the liturgical cycle with all its variables that appear in each year, the Church seeks to infuse man's earthly life with the grace of eternity, by sanctifying through ceaseless prayer all the calendar subdivisions of time. This gives them a new finality and places them in four concentric circles: 'the day', with its various divisions, 'the week, the month', and 'the year', hence polarising the entire human life, in its most important circumstances and moments (Branişte 1993:128).

\section{The liturgical year and its subdivisions}

The liturgical day, although in connection with the astronomical day that measures the duration of a full rotation of the Earth around its axis, does not identify with the latter. This is so because, following the Jewish tradition, the liturgical day begins in the evening and not at midnight, as shown in the biblical report on creation: 'and the evening and the morning were the first day' (Gn 1:5).

As a result, the liturgical day begins the night before, with the Vespers - the evening service and the first among the seven church Lauds - and is dedicated to a moment or event in the history of salvation, or in the life and activity of the saviour, the Blessed Virgin, the Holy Apostles and of certain saints, according to what the church has established over time.

During a liturgical day, the church celebrates the full cycle of the seven offices (Vespers, Compline, Midnight Service, Matins with the first, third, sixth and ninth Hours), whose matrix has both Hebraic and Patristic roots, as they emerged around the 2 nd -4 th centuries. In time, they were layered with poetic creations of famous hymnographers such as St. John Damascene, St. Cosmas of Maiuma, St. Sophronius of Jerusalem, etc. Then, in the 8th-9th centuries, they were enriched by the contribution of theologians from the Stoudite Monasteries and later by those from Mount Athos (10th century). Their final consecration took place with the advent of the printing press in the 15th century (Branişte 1985:38-40).

All these offices are nothing else other than the preparation of the mystical meeting with Christ in the Holy Liturgy, a service that marks the peak and centre of a liturgical day, and during which the entire history of salvation is 're-actualised'. This 're-actualisation' is not done in a commemorative chronological-historical manner, but in a mysterious, symbolic and eschatological way, where all history - from the moment of creation and up to Parousia - is summarised in the mystical and sacramental presence of Christ that gradually increases until it reaches its fullness and actuality in the Eucharist (Branişte 1993:129-130).

The liturgical week is made up of a cycle of seven liturgical days that are crowned with the Sunday - the Day of the Lord. The division of time into weeks was characteristic of people who used the lunar calendar, and especially of the Jewish people, who had borrowed it from the Asyro-Babylonians.

However, the religious consecration of the weekly cycle is much older in the tradition of the Old Testament, as the biblical account on creation presents God's work by which he brought everything into existence in 6 days, which he followed by a day of 'pause', when he 'rested', that is, he no longer created other forms of existence but started to care for his already made creation.

God's creative act, as presented in the Book of Genesis, has thus become the model, the rule and the measuring unit for human life: 6 days of work, and one of rest. In terms of time measurement, the Christian Church has inherited from the Jewish tradition the 'week', as well as its structure, by which 
Sunday is considered the first and most important day of the week (Oancea 2007:216-217).

Hence, the liturgical week starts on Sunday, that is, at the previous Saturday night Vespers, and ends on the next Saturday, after the last day service, the Ninth Hour is completed. The cycle of weeks in the Orthodox Church year begins with the 'Bright Week' - the first week after Easter and concludes with the 'Holy Week' of the Passions right before the following Easter. These represent the essence of the entire ecclesiastical year and are inextricably connected. In terms of the calendar, an important place is held by the following: the week before and the week after 'Pentecost', the weeks before and after the 'Elevation of the Holy Cross' (September 14) and the weeks before and after the feasts of 'Nativity' and 'Baptism of the Lord' (Streza 2011:75-76).

Also, because the lives of Christians have always been related to Christ and his brilliantly fulfilled work in the saints, each of the seven days of the week is dedicated to an important event in connection with the Person of the Saviour and of some of the saints, in which he 'is resting'.

Therefore, 'Sunday' is the day of the 'Lord's Resurrection', the core event of Christianity.

'Monday' is dedicated to the veneration of the 'Holy Angels' whom God created before men. They are the intercessors and protectors of men, sent by God to herald his will to the world.

'Tuesday' is dedicated to the commemoration of 'Saint John, the Prophet, Forerunner and Baptist of the Lord', who is the last and greatest of all the prophets and righteous people of the Old Testament, as the saviour himself characterised him (Lk 7:27). However, recent research shows that Monday and Tuesday have two sets of themes, one of which is repentance (See: Getcha 2012:24; Krasheninnikova 1996:260-261).

'Wednesday' and 'Friday' are dedicated to the 'Holy Cross' and 'Holy Passion of the Lord', because the assembly of the scribes, chief priests and elders, followed by Jesus' betrayal and arrest took place on a Wednesday, and Friday, the day before the Paschal Sabbath, was the day when the saviour was crucified for the salvation and redemption of men.

'Thursday' is dedicated to the 'Holy Apostles', because it was on this day that the 'Mystical Supper' took place, when the saviour instituted the Mystery of the Holy Eucharist, in the presence of His Apostles. These chosen men enjoy a weekly liturgical commemoration, as they were the closest to the Lord and his direct disciples, and it was them that the Lord entrusted with the preaching and spreading of the Christian faith, which made them the foundation layers or 'pillars of the Church'. 'Saint Hierarch Nicholas', the Archbishop of Myra in Lycia, one of the most well-known saints throughout the entire Christianity, is also remembered on Thursdays as a representative of the 'Holy Hierarchical Fathers', who are considered the descendants and continuators of the Holy
Apostles, as persons through which Christ worked and perfected the 'oeconomy' of salvation.

'Saturday' is generally dedicated to the remembrance of 'all the dead', and yet first and foremost of the 'holy confessors and martyrs', who gave their lives for Christ or suffered for the victory of the Christian faith in the world. The reasons for this commemoration are based on the fact that, on this day, the body of the Lord was laid in the grave, while he went down into hell with his soul and deity, to lose the souls of all the righteous people of the Old Law. Also, from an Old Testament point of view, Saturday is the day when God took a break from his creative work, and thus this day becomes a symbolic foreshadowing of the eternal and joyous rest that the saints and righteous partake of in God's kingdom (Branişte 1993:131-132; on the themes of the days of the liturgical week, see also: Krasheninnikova 1996:260-268).

The liturgical month is a unit of time with lesser importance in the context of the Orthodox Church worship, especially when compared to the civil calendar, wherein a month is a unit of time measurement with particular relevance in all areas of social life. Yet, precisely because the church has always adapted to civil time by synchronising with it, although it is organically above time, the month was adopted in the liturgical calendar as a subdivision of the church year, and as a result, it gave birth to the 12-month 'Menaions' (from Gr. 'Minos-month'), corresponding to the months of the year.

The liturgical year, though it largely follows the structure of the civil year, does not start on January 1, but on September 1 , because of biblical reasons, both on account of the Old Testament, as it is considered the day when God began the Creation of the world, and based on the New Testament, as this is the day when the saviour is considered to have started his public activity by reading from the prophecy of Isaiah in the synagogue (61:1-2): 'The Spirit of the Lord is upon me because he hath anointed me to preach the gospel to the poor ... To preach the acceptable year of the Lord ...' (Lk 4:18-19). Another perspective shows that in the early Constantinople rite, September 01 was the start of the civil year and Christian New Year was on September 23. For this reason, the first feast of the year, the Conception of St. John the Baptist, was set to this day (Mateos 1962:55).

The Sacrifice and Resurrection of Christ are the essence and centre of the history of salvation, so much so, that the pinnacle and foundation of the liturgical year is the Feast of the Resurrection, preceded by the Great Week of the Holy Passions, and followed by the Bright Week of the Paschal joy.

Following the completion of the liturgical cycles of various feasts, the Orthodox church year seeks both the gradual actualisation of Christ's life and the redemptive activity - this liturgical cycle is in close dependency with the changing date of Easter, which is based on the lunar calendar - and the commemoration of the saints, which was established in close 
connection with the solar calendar that corresponds to the civil calendar (Streza 2014b:226-227).

As the liturgical year is centred on the feast of Holy Pascha, it can be divided into three major parts, named after the main books used in the church services during each of those parts, namely:

- 'The Triodion' (meaning 'three odes', a particular canon read in church during the services, which is made up of three songs - odes) is the pre-Paschal period starting from the 'Sunday of the Publican and the Pharisee', which always falls three weeks before the beginning of the Great Lent, and ending on the Holy Saturday, the day before Pascha. The first three weeks of this period are focused on the spiritual preparation of the Christians for the beginning of the fast, and the actual seven weeks of the Great Lent represent a spiritual ascent that each man embarks on along with Christ to experience the great mystery of his sacrifice and resurrection with him, in a mystical-sacramental manner (Schmemann 1998:10-15).

'The Pentecostarion' (from Gr. 'Pentecoste' - the fiftieth [day]) starts on Easter Sunday and finishes on the first Sunday after Pentecost - the Sunday of All Saints, thus lasting eight weeks, where the two constitutive feasts of Christianity - the Easter and the Pentecost - represent a perpetual culmination of the joy of living in Christ.

'The Octoechos' (meaning eight 'eh's' or tones) covers the rest of the year, from the end of Pentecostarion and up to the beginning of the Triodion, and it is the longest liturgical period in the church year. It lasts between 26 and 40 weeks, depending on the variable date of the Easter over twoconsecutive years, and is centred on the Nativity and Baptism of Christ, two feasts that, along with the adjacent Circumcision and Presentation of the Lord, represent the peak liturgical moments of the entire Octoechos.

In connection with this period, the principle of the Octoechos was born within the Church worship, which implied the liturgical organisation of the hymns in eight consecutive weeks, to be sung on eight different tones, each week thus forming a cycle that is repeated over and over. This principle does not relate merely to the arrangement of liturgical chants on the eight liturgical tones, but it rather refers to the hymnography theology of the first eight weeks following the Pascha. In this way, the musical significance of the Octoechos whose origin is associated with Severus of Antioch, at the end of the 5th century - became very much obscured, and the arrangement on church tones as we know it to be today in the Orthodox Church was attested only in manuscripts dating from the 11th to 13th centuries. (Werner 1948:223-229) However, recent research places the origins of the system of the eight tones back to the 7th century (see: Frøyshov 2007:139-178; Jeffery 1991:52-75).

Therefore, the structure of the Orthodox liturgical year is based on the combination of two concentric, yet different temporal cycles of liturgical feasts or days:
- 'The variable liturgical cycle' that refers to feasts whose date varies from one year to another, that revolves around the feast of Pascha and exclusively have at their core the person and activity of the Saviour, whom the church glorifies over the whole course of the year through the hymns of the Octoechos, the Triodion and the Pentecostarion; it is also called the 'Christological or Paschal cycle'.

- 'The fixed liturgical cycle' commemorating in particular the chain of saints who are remembered every single day during the 12 months of the calendar year, starting in September and ending with August; it is also called the 'mineal cycle'. As an exception from this scheme, it must be mentioned that the feast of Nativity, along with all the other feasts that are correlated to it - the Lord's Baptism, Circumcision and Presentation at the Temple - which are highly important celebrations of the Saviour's life and closely related to the solar calendar, represent the crown of the daily feast cycle of the Saints (Streza 2011:77-78).

Hence, each liturgical day in the church year belongs simultaneously to both cycles: as a day of the week, it belongs to the Paschal or Christological cycle, and as a day of the month it belongs to the mineal cycle. For that reason, but for a few exceptions that are indicated by the Typikon, all the divine services of a liturgical day unfold according to this double relation, whose result brings forth a combination of the various chants from the Octoechos (from the Triodion or Pentecostarion respectively) with those from the Menaion of that month.

Therefore, the Christian year reflects the symbiosis between various ecclesiastical traditions, which have never been based upon a divine revelation. It is rather a concept that is always subject to improvements by the ecclesiastical law. Throughout history, each independent church has reserved the right to adjust the church year according to its specific needs and conditions, resulting in a great variety of certain patterns of the year in the several churches of the East and the West. Unfortunately, this variety combined with the issue of the civil calendar corrections is the subject of serious controversies that generate separation not only between Eastern and Western Churches, but also within the Orthodox Churches as well (See: Shepherd 2019:passim).

\section{The theological structure of the liturgical year}

In terms of the theological reasons for the origin and evolution of the liturgical year, it should be noted that the fundamental principle of the church year is closely linked to the Apostolic period at the dawn of the Church because the Church has always been aware that it represents the 'New Israel', and that it was meant to perfect the fate of the chosen people in general, and that of the Mosaic cult in particular. The entire Judaic tradition was not only annulled and disowned by the Incarnation of Christ, the Giver of the New Law, but it is Christ himself who fulfilled all the rituals and traditions of 
the law, thus proving himself the most pious of all Jews, as he observed all the rituals of the law - starting from his circumcision and going through all the Judaic holidays. In this sense, his words are defining: 'Do not think that I came to destroy the Law or the Prophets. I did not come to destroy but to fulfil ...' (Mt 5:17).

That explains the fact that early Christians continued to take part in temple services first, and then assembled in Christian house gatherings, where they performed the 'Breaking of the Bread' (Ac 2:47). It also explains the fact that the central feasts of Judaism - the Passover and Pentecost - were safeguarded by Christianity from the very beginning, although, in truth, they were also kept because of the significance of the special events fulfilled by Christ on those holidays, that is, his resurrection and the birth of the church under the descent of the holy spirit (Baumstark 1953:174-176).

Regarding Pascha and Pentecost, it is often attested, both in the New Testament and in other Christian writings dating from the 1st to 2nd centuries, that the church kept these feasts not out of inertia, but because they had become the biblicalliturgical foundation of the faith of the church, because of their newly acquired meaning in and through Christ. Christ is the New Pascha, who fulfils the symbolic-liturgical prefiguration of the Passover in Judaism through his sacrifice and resurrection, whereas on the day of Pentecost, which was endowed with a pronounced eschatological character in late Judaism, Christ visibly founded the church by sending the Holy Spirit over the Apostles and disciples, an event that marked beyond the shadow of a doubt the beginning of the time of God's Kingdom in the world.

In this sense, the Eucharist and the Lord's Day had a predominantly Paschal character from the beginning, and the mysteries of Christian initiation were perceived as an extension of the Pentecost, a continual outpouring of the Holy Spirit and his gifts. Therefore, the reason why Christians celebrated the Easter and the Pentecost must be sought in the fact that the early Church adopted the Jewish theology of the time, whose expression was these two holidays (Von Rad 1962:105-109).

Thus, these feasts acquired their full significance and a new meaning in Christ-Messiah, namely that the eschatological Kingdom of God is present, yet mystically hidden in the world, only to be fully revealed on the last day. Through his sacrifice, Christ established the Christian Pascha as a symbol of the new dimension embraced by the salvation history, which is oriented toward perfecting the Pascha on the day that has no evening in the Kingdom of God.

The Pentecost is celebrated 50 days after the Pascha, and its presence in the calendar of the Primary Church represents a special expression of the theology of the time, of natural cycles, with a close connection with the eschatological reality of the kingdom. In this respect, it should be noted that the Pentecost, which was originally an agricultural celebration, went through a profound transformation during Rabbinic Judaism, which turned it into a historical commemoration of the Decalogue given on Sinai (Strassfeld \& Eisen 1993:145-151).

'If this transformation happened in the time of the Gospels', McArthur (1953) notes:

$[I] \mathrm{t}$ is remarkable that the disciples received the Holy Spirit in His dynamic power that same day. Just as the Old Covenant, established at the Exodus and remembered at the Jewish Passover, was fulfilled on Sinai, in the same way, the New Covenant established through the events recalled by the Christian Pascha was perfected at the Pentecost. Thus, the Christian Pentecost became the birthday of the Church as God's New Israel. (p. 143)

The Jewish Pascha originating in the Exodus of the people from the Egyptian captivity had been a symbolic prefiguration of the real Pascha. This fact has led to a general tendency in the Primary Church to relate to Christ as 'The Lamb of God', who sacrificed himself for the salvation of the world. Consequently, the Paschal mystery of Christ's mystical sacramental presence has been, ever since the beginning of Christianity, the foundation and essence of the entire Christian faith and life, in all their dimensions. In this respect, the words uttered by St. Ap. Paul are defining: 'And if Christ has not been raised, then our preaching is empty, and your faith is also empty ...' (1 Cor 15:14).

As theological controversies on the divine-human person of the saviour arose, the Church went on to formulate and clarify its credenda and precepts, which reverberated throughout the liturgical worship, because only the liturgical reception of dogmas and teachings by the entire church validates them as authentic and in accord with the tradition entrusted to the Holy Apostles by Christ. Thus, came to light the 'theology of Incarnation' that completes and sustains the 'theology of Atonement and Salvation', so that the Paschal cycle, which is centred on the saviour's sacrifice and resurrection and actualised according to the variability of the lunar cycle relating to the solar one, acquires a new dimension in the cycle of the fixed holidays that focalises on the Lord's nativity (Streza 2011:78-79).

All the feasts that anticipate, precede and follow the Pascha are but a preparation, an ascension toward Resurrection, a means to make it permanent. For that reason, the entire worship of the Church has a predominantly 'Paschal character', wherein the various forms of liturgical expression highlight the multiple senses and facets of the Mystery of Sacrifice and Resurrection, which is the foundation and purpose of Christian faith and life (Dalmais 1961:218).

Centred on the Lord's passion and sacrifice, by which the entire creation was restored and reinstated in communion with God, the 'Triodion period' reaffirms the saviour's status of hierarch and his activity as high priest, as he is the one who journeys alongside every believer in their spiritual ascent toward resurrection. This spiritually exalting journey 
is brought forward by the church in the themes covered by the Sundays of this period, which are characterised by an intense spiritual zeal.

In anticipation of this period, which Christ himself gifts to his followers so that they might be cleansed and illumined, the Church placed 'Zacchaeus Sunday' right before the beginning of the Triodion. The theme of this Sunday represents the foundation of Christian life: 'the hunger and thirst after God', that is, man's ontological desire to enter the eternal communion in the love of God (Daniel 2008:13-32).

The 'Sunday of the Publican and the Pharisee' opens this prePaschal period with a focus on the objective way in which the believer is called to assume this spiritual ascent: 'through humble prayer'. Next, the church proposes the attainment of a new spiritual level through the theme of the following 'Sunday of the Prodigal Son', namely 'true repentance and return from the foreign land of $\sin ^{\prime}$. The following 'Sunday of the Last Judgement' will give way to a new dimension of the spiritual life, one that is marked by the essential virtue of 'charity through philanthropy'. The last of the pre-Lenten Sundays, dedicated to 'Adam's expulsion from Paradise', places before the faithful the 'hope for forgiveness' and the possibility to regain their place in Eden through fasting and prayers (Schmemann 1998:28-32).

All the Lenten Sundays have a special significance and offer models of authentic spiritual life. In their middle stands the very 'Cross of the Lord', the ultimate expression of his passion, but also of his redeeming power - the week that halves the Lent is the one that starts with the third Sunday, also known as the 'Sunday of the Veneration of the Holy Cross'. While the first Lenten Sunday - the 'Sunday of Orthodoxy' - celebrates 'true faith' understood as anticipation and hope of attaining the heavenly kingdom and provides the right foundation for living an authentic spiritual life, the second, fourth and fifth Sundays of the Lent are devoted to some worthy-to-follow models of sanctity: Saint Gregory Palamas, Saint John Climacus and Saint Mary of Egypt. 'Palm Sunday', The Entrance of Christ into Jerusalem, shines, through its anticipatory joy, the wealth of gifts brought about by the Passions and Resurrection of Christ who, by his humble human-like, unto death obedience to God, conquered death, and the caducity of man's existential condition after the Fall (Daniel 2008:143-176).

The 'Sunday of the Resurrection' opens yet another chapter in the worship cycle of the Church, a period filled with the joy of the victory of the resurrected Christ, the 'Pentecostarion' period. This represents and actualises the events full of significance that ensue after the resurrection of the Lord, that is, his ascension to heaven, followed by the birth of the church through the descent of the holy spirit. This liturgical period that begins on Holy Pascha Sunday and ends on the Sunday following the Descent of the Holy Spirit, which is called the 'Sunday of All Saints', is centred on the actual presence of the glorified and transfigured Christ who reveals himself to his disciples after his resurrection and presents the saviour as the king and founder of his church. Therefore, this period expresses and communicates to all Christ's victory over sin and death, the Paschal triumph and joy that is the crown of the entire Lenten compunction and struggle against sin (Streza 2014a:110-112).

The three main feasts of the Pentecostarion divide it into three parts, all of which are marked by the specificity of one of these feasts: the Resurrection, the Ascension to Heaven and the Descent of the Holy Spirit. Thus, the first period that lies between the resurrection and the ascension is dominated by the Paschal, joy-filled character of its liturgical services, with a more accented tonality during the first week, when the church does not herald or praise anything else but the resurrection of the saviour. The 'Lord's Resurrection' is the essence of Christian spirituality and the life of the church, and Pascha remains the central mystery of the Orthodox worship, mystically shining its redemptive rays, liturgy by liturgy, throughout the entire Orthodox liturgical year (Pătrunjel 1998:28-29).

The second division extends from the Lord's Ascension into heaven to the Pentecost and is centred on the feast of 'Ascension', which is the second great feast of the Pentecostarion period. The joy of our Lord's Resurrection is amplified and reinforced by the significance of this feast that focuses on the dead and resurrected saviour who is glorified by his ascension into heaven. His act unlocked for all the path that leads to God the Father; his promise to send the Holy Spirit in the world once fulfilled there emerged cis Church, the place wherein Christ would forever and ever remain in communion with his faithful (Pătrunjel 1998:42-56).

The promise made by the saviour at his ascension is fulfilled at 'Pentecost', a feast that is celebrated at the end of the Pentecostarion period, when the Church actualises the descent of the Holy Spirit. This is the very day that Christ founded the church by extending his fully deified body in all those who believe in him and open up to him in faith. For seven days, starting with the Saturday before the feast and ending on the following Saturday, the faithful rejoice and honour it as a celebration of the church herself, as it is the feast of the fullness of God's gifts, which are infused and cultivated in the souls of the believers by the Holy Spirit in the church. The importance of this feast is also reflected in the succession of Sundays for almost the entire liturgical year, made with reference to the Sunday of Pentecost (Pătrunjel 1998:57-68).

The 'Octoechos period' that lasts from the 'Sunday of All Saints' to the 'Sunday of the Publican and the Pharisee' commemorates and actualises the events in the 'oeconomy' of salvation preceding the Passion of Christ. This liturgical period focuses primarily on the 'Prophetic Office' of the Lord, by which he gave the world the gift of his gospel and its divine teaching. However, this theological interpretation of the Octoechos is based on the deep symbolism and 
importance of the 'Eighth Day - the image of eternity' - in the life of the church. In this sense, it is important to mention that the various non-Christian visions and interpretations of anything calendar-related, or the Greek philosophers' mystical-symbolic representations and speculations regarding the 'number eight' in the first Christian centuries, fail to account for the explanations given to the genesis of the theological and liturgical-symbolic senses that the Octoechos and the other liturgical services possess. At the very most, there were somesuggestions received from the aforementioned ideas and translated in the artistic and ritualistic expressions of the life of the Church, which has always functioned under the unshattered rule of the liturgical.

The theological foundation of the Octoechos period in the Christian Church lies in the very liturgical symbolism and the theology of the 'eighth day', which presents the course of time during the church year as a time when Christians prepare for the eternal life and become mystically acquainted with the eschaton through their participation in the liturgical cycles in the Church. This 'eighth day' was named by St. Basil the Great 'icon of the age to come', and by St. Maximus the Confessor, 'the immortal and eternal age', in which, 'the temporal nature has reached its end', and was summarised by St. John of Damascus as follows: 'the eighth age is the age that is to come... a single day that has no evening when the sun of righteousness shall shine brightly upon the righteous' (Streza 2011:79-81).

The church year begins on 01 September. The first feast of the year, the 'Nativity of the Most Holy Theotokos', corresponds to the beginning of the New Testament history, and the last great feast of the year, also dedicated to the Holy Mother of God, is the 'Dormition of the Theotokos'. In Her Typikon, which was finalised during the first millennium, the church has established a logical sequential principle that serves as the foundation for the entire liturgical life, in the sense that the choice of texts for the services throughout the year is defined by an adequate order and harmony. In this regard, the excerpts from Gospels mould perfectly onto the feasts to which they are assigned. Moreover, the whole sequence of scripture readings has a sense and logic that is at the same time symbolic, theological, and 'chronological', because each evangelist had arranged the ideas of their Gospel.

The cycle of the fixed date - 'mineal' - feasts of the Synaxarion, 're-actualises' the life of the saviour along with that of all the holy persons that lived throughout the entire oeconomy of salvation and history of the church, that is, the prophets and righteous people before Christ, who had waited for and prophesied about him, as well as the Holy Apostles and martyrs and all the saints who followed him and gave their lives for Christ and his Church. Thus, the Paschal cycle of the liturgical year is completed by its cycle of 'mineal' feasts.

However, these commemorations are not mere anamneses, for, in each feast, the celebrated saints extend to all the faithful the spiritual gifts that they were endowed within the Heavenly Kingdom, by the power of the Holy Spirit. Christ is as such communicated to the faithful not only as an individual divine person but also as a unique and specific presence in the persons of all his saints. In other words, the saviour pours out his love in a personalised manner as well, by making his believers part of the love and wonderful gifts radiating from the presence of his saints, thus proving that the earthly church is tightly and joyfully bound to the heavenly one (Pătru 2004:24-25).

\section{Conclusion}

Each new church year reiterates more than a summary of the 'oeconomy' of salvation that is renewed in the liturgical services; it represents a call for Christ's followers to grow in faith and reach a more profound experience and self-giving state by taking part in the communion at the Table of the Kingdom, a communion that Christ is already giving to the world in a mystical, yet real way.

Therefore, the liturgical year is very important through its profound meanings; it represents the Apostolic essence of the life of the church - especially through the succession of Gospel readings, and also of the other writings from the holy scriptures that lie at the bases of its feasts.

Within the confines of historic time and human experience, the Orthodox liturgical year is constantly renewing and perfecting each person's life with and in Christ, by having the historic life of the Saviour mystically extended in the souls of the faithful, for 'Jesus Christ the same yesterday, and today, and forever' (Heb 13:8).

The orthodox perspective reveals each liturgical day as a feast, a possibility for time to open towards eternity. This is the time of the church, the eternity of God's love opened to every believer in a unique, specific, yet always novel manner.

\section{Acknowledgements Competing interests}

The author declares that he has no financial or personal relationships that may have inappropriately influenced him in writing this article.

\section{Author's contributions}

D.A.S. is the sole author of this article.

\section{Ethical considerations}

This article followed all ethical standards for research without direct contact with human or animal subjects.

\section{Funding information}

This research received no specific grant from any funding agency in the public, commercial or not-for-profit sectors. 


\section{Data availability}

Data sharing is not applicable to this article as no new data were created or analysed in this study.

\section{Disclaimer}

The views and opinions expressed in this article are those of the author and do not necessarily reflect the official policy or position of any affiliated agency of the author and the publisher.

\section{References}

Baumstark, A., 1953, Liturgie Comparée [Compared Liturgics], Éditions Chevetogne, Chevetogne/Paris, pp. 174-179.

Branişte, E., 1985, Liturgica specială [Special Liturgics], Editura Institutului biblic și de misiune al Bisericii Ortodoxe Române (IBMBOR), Bucureşti, [Bucharest].

Branişte, E., 1993, Liturgica generală [General Liturgics], Editura Institutului biblic și de misiune al Bisericii Ortodoxe Române (IBMBOR), București [Bucharest].

Dalmais, I.H., 1961, Introduction to the Liturgy, Helicon Press, Baltimore, MD.

Daniel, The Patriarch of the Romanian Orthodox Church, 2008, Foame și sete după Dumnezeu - intelesul si folosul postului [Hungry and thirsty for God - The significance and use of fasting], Basilica, Bucharest.Frøyshov, S., 2007, 'The early development of the Liturgical eight-mode system in Jerusalem', St. Vladimir's Theological Quarterly 51(2/3), 139-178.

Getcha, J., 2012, The Typikon decoded, St Vladimir's Seminary Press, Yonkers, NY

Jeffery, P., 1991, 'The Sunday office of seventh-century Jerusalem in the Georgian Chantbook (ladgari): A preliminary report', Studia Liturgica 21(1), 52-75. https:// doi.org/10.1177/003932079102100106

Krasheninnikova, О., 1996, 'К истории формирования седмичных памятей Октоиха' [On the history of the formation of weekly memories of Oktoich], Богословские труды [Theological Works] 32, 260-268.

Mateos, J., 1962, Le Typicon de la Grande Eglise, vol. I, Pont. Institutum Orientalium Studiorum, Roma.
McArthur, A.A., 1953, The evolution of the Christian year, SCM, London.

Oancea, C., 2007, 'Concepţia liturgică asupra creației si a destinului ei în Pentateuh' [The Liturgical view of creation and its destiny in Pentateuh], in D. Oancea \& C. Necula (eds.), 'Ale Tale dintru ale Tale' Liturghie - Pastorație - Mărturisire ['Your own of Your own' Liturgy - Pastoration - Confession], pp. 209-218, Andreiana, Sibiu.

Pătru, A., 2004, 'Die heiligen Mysterien/Sakramente' [The holy sacraments], in G. Barth, L. Dobrescu \& A. Pătru (eds.) Deutsch-rumänische Schriften zum Jungen Dialog [Romanian-German writings to youth dialogue], pp. 23-28, Vol. II., Hanovra. edn., Kirchenamt der EKD, Hannover.

Pătrunjel, S., 1998, Die orthodoxe Spiritualität der Osterzeit. Kommentar zum Pentekostarion [The orthodox spirituality of easter period. Comment on the Pentekostarion], Der Christliche Osten [The Christian East], Würzburg.

Schmemann, A., 1998, Postul Mare [The great lent], Doris, Bucharest.

Schmemann, A., 2002, Introducere în teologia liturgică [Introduction to the Liturgical theology], pp. 138-139, Sophia, Bucureşti [Bucharest].

Shepherd, M.H., 2019, 'Church year', Encyclopedia Britannica, viewed 01 July 2021, from https://www.britannica.com/topic/church-year.

Strassfeld, M. \& Eisen, A.M., 1993, Jewish holidays, Harper-Collins Publishers, New York, NY.

Streza, C., 2014a, 'The holy Eucharist - Nourishment for the eternal life, and the power to surrender one's entire life to God', International Journal of Orthodox Theology 5(3), 107-139.

Streza, D.A., 2011, Sărbătoarea Naşterii Domnului: Originea, evoluţia şi importanţa e in cadrul anului liturgic [The feast of the nativity of Christ: Its origins, evolution and relevance in the Christian Liturgical year], Andreiana, Sibiu.

Streza, D.A., 2014b, The Christian calendar and the historical birth date of the Lord, Revista Mitropolia Olteniei [The Oltenia Archidiocese Review], No. 1-4, Craiova, Romania, 225-247, s.n.

Streza, D.A., 2017, 'Aspecte ontologice ale timpului liturgic' [Ontological aspects of Liturgical time], Revista Teologică [Theological Review], 3, 139-151.

Talley, J.T., 1991, The origins of the liturgical year, 2nd amended edn., Litugical Press, Collegeville, MN.

Vismans, T. \& Hollaardt, A., 1965, 'Kirchenjahr' [Liturgical year], in L. Brinkhoff (ed.), Liturgisches Wörterbuch [Liturgical dictionary], pp. 1303-1310, J.J. Romen, Roermond.

Von Rad, G., 1962, Old Testament theology, Harper Collins, San Francisco, CA.

Werner, E., 1948, 'The origin of the eight modes of music (Octoechos) - A study in musical symbolism', in Hebrew Union College Annual, XXI, pp. 223-229, s.n., Cincinnati, $\mathrm{OH}$. 